\title{
Lumbar Intradural Metastasis from Large Cell Neuroendocrine Carcinoma of the Lung
}

\section{Akciğer Büyük Hücreli Karsinomunun Lumbar Intradural Metastazı}

\author{
Ayse Karatas ${ }^{1}$, Umit Zeydoglu ${ }^{1}$, Ahmet Alacacioglu ${ }^{2}$, Ayse Yagci $^{3}$ \\ ${ }^{1}$ Bozyaka Eğitim Ve Araştırma Hastanesi, Beyin Cerrahisi, İzmir, Türkiye \\ ${ }^{2}$ Katip Çelebi Üniversitesi, Atatürk Eğitim Ve Araştırma Hastanesi, Tıbbi Onkoloji Kliniği, İzmir, Türkiye \\ ${ }^{3}$ Bozyaka Eğitim Ve Araştırma Hastanesi, Patoloji Kliniği, İzmir, Türkiye
}

Doi:10.5505/aot.2013.70288

\section{ÖZET}

Spinal metastaz malignitelerde sık görülen bir bulgu olmasına rağmen intradural ekstrameduller metastazı (IDEM) çok nadirdir. Biz 55 yaşında erkek hastada lomber omurgada intradural metastaz ile presente olan akciğerin büyük hücreli nöroendokrin karsinom olgusunu sunuyoruz.

Anahtar Kelimeler: Tümör; Intradural metastaz; Akciğer kanseri

\begin{abstract}
Although spinal metastasis is a common finding in malignancies, however intradural extramedullary metastasis (IDEM) is very rare. We report a 55-year-old man, known case of a large cell neuroendocrine carcinoma of the lung with IDEM in lumbar spine.
\end{abstract}

Key words: Tumor; Intradural Metastasis; Lung cancer

\section{Introduction}

IDEMs are rare, originated from visceral neoplasia (\%3.6) and particularly neuroendocrine tumors $(1,2)$. Literature consists of case reports and reviews of small series. Carcinoid tumours are neuroendocrine cell originated malignant tumours (3). Usually, intradural carcinoma metastasis occur with past cure systemic cancer and indicate a short survival time (4-7). The optimal treatment is still controversial, with choices including steroids, radiation, chemotherapy and surgery $(4,7)$. Surgery provides decompression of functional neural tissue and histological confirmation of tumor. This report presents a case of a lumbar radiculopathy caused by a intradural extramedullary metastasis from large cell neuroendocrine carcinoma of the lung

\section{Case Report}

A 55 year-old-man admitted to our clinic with a 2-month history of lower back and left leg pain. He was known to have large cell neuroendocrine carcinoma of the lung (T1N2M0 stage 3A), which had been diagnosed 2 years ago. $\mathrm{He}$ received neoadjuvant chemotherapy than underwent large pneumonectomy with lymphatic dissection. After surgery he received radiotherapy.His neurological examination was normal. Magnetic resonance imaging (MRI) revealed a homogenously enhancing intradural extramedullary $1 \times 2 \mathrm{~cm}$ sized solid mass at $\mathrm{L} 4$ level, without adjacent-vertebral signal abnormality (Figure 1). Through a L4 total laminectomy with subsequent median durotomy. Tumour was haemorrhagic, welldefined, slightly attached to rootlets which was completely removed under the operating microscope. The histopathological examination considered a large cell neuroendocrine carcinoid metastasis from lung (Figure 2). Immunohistochemical tests revealed positive sitokeratin, epithelial membrane antigen, thyroid transcription factor-1, neuron specific enolase, chromogranine, synaptophysin and P53. The Ki-67 labelling index was \%80. The patient lower back and left leg pain resolved immediately after surgery and also he had not neurological deficit. The patient was transferred to oncology department for following treatment. 


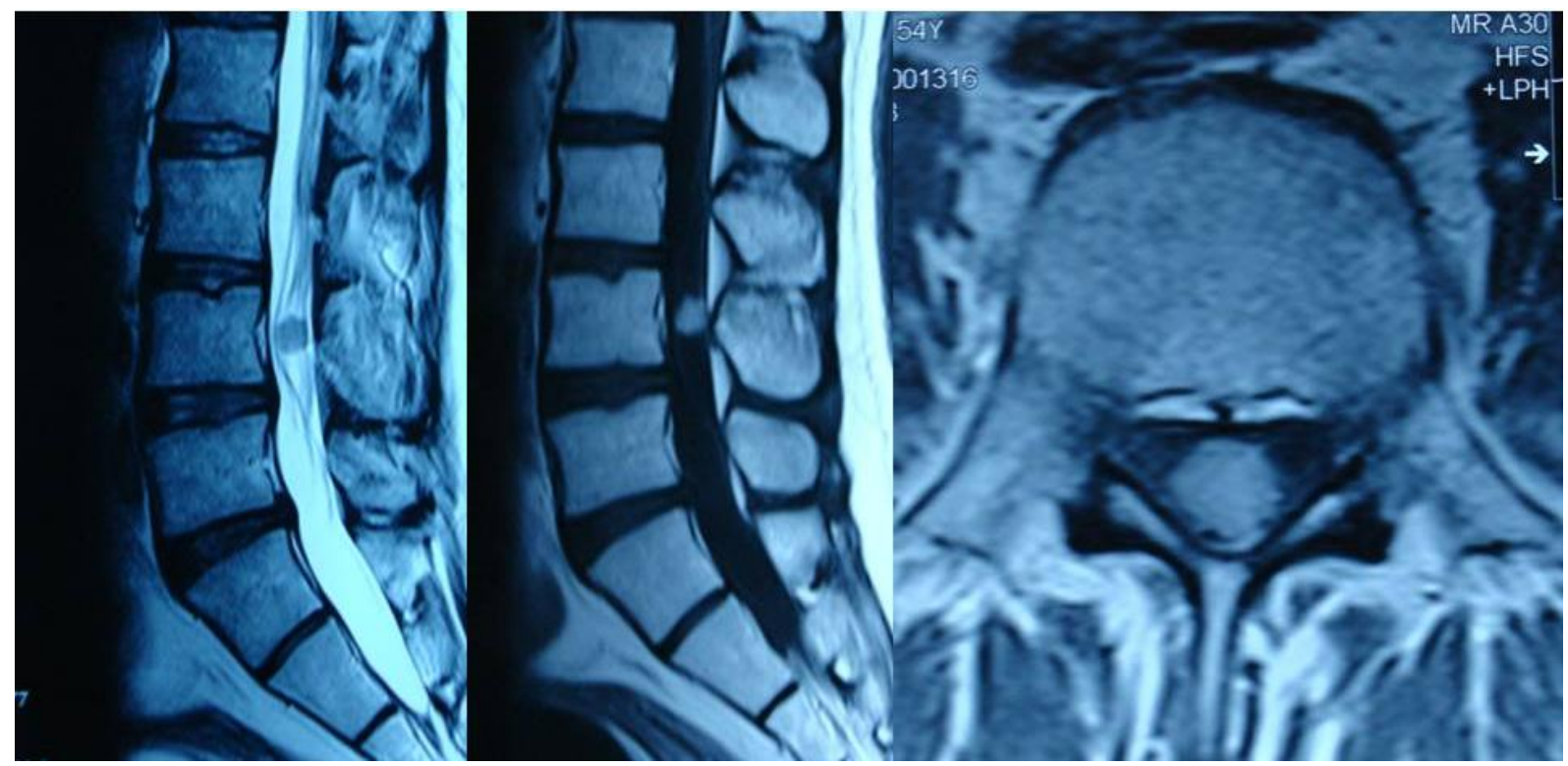

Figure 1. MRI scans showing an intradural well-circumscribed L4 dorsally located lesion a sagittal T2; $\mathbf{b}$ and $\mathbf{c}$ sagittal and axial T1-weighted images with gadolinium contrast, respectively.

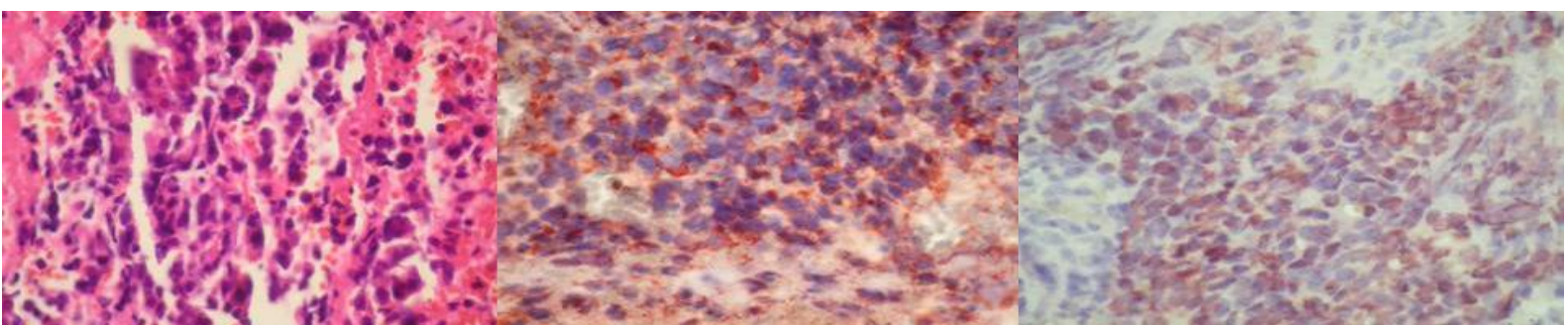

Figure 2.a Pathological samples of the tumourcell groups which are showing large and hyperchromatic nucleus. (H\&Ex200); b and c synaptophysin and chromogranin positivity immunoreactivity in tumor cells, respectively (Synaptophysinx200), (Chromograninx200).

\section{Discussion}

IDEMs are very rare and appear from extended systemic cancer (2,6-8). It has been reported $5 \%$ of cases of metastatic disease to the spine occur in intradural extramedullary region $(4,7,9)$. Most of the cases occur in the 6th decade $(4,7)$. Lung and breast carcinomas accounted for a majority of the cases which are mostly located in the lumbar spine $(4,5,7)$. Tumour usually $(60 \%)$ localizes dorsolaterally (4). Although intramedullary lung cancer metastases arise frequently from small cell, IDEMs originate mostly from adenocarcinomas (7). The World Health Organization categorized large cell neuroendocrine carcinoma as non-small cell lung carcinoma (10). Large cell neuroendocrine Adressforcorrespondence: Doç. Dr. Ahmet Alacacioglu

e-mali: dralaca2000@yahoo.com

Available at www.actaoncologicaturcica.com

Copyright @Ankara Onkoloji Hastanesi carcinoma of the lung is quite aggressive tumour. It is characterized by neuroendocrine morphology and high-grade appearance. Neuroendocrine tumor is identified with immunohistochemical markers such as synaptophysin, chromogranin, and neuron specific enolase (10). Metastases causes spinal cord compression by growing from vertabrae, epidural region, or intradurally (3). Possible dissemination pathways to the spine are hematogenous, retrograde venous transport, cerebro spinal fluid mediation, perineural lymphatic transport and trans dural invasion $(2,4,7,9)$. IDEMs have no specific clinical presentation; their diagnosis is based on radiological exploration (2). In our case, only radicular pain was seen as a representing symptom. At the time of the diagnosis of a metastatic carcinoma of the lung, most patients 
have systemic metastases, especially brain metastases (7). Thus, the brain and spinal cord should be screened by MRI. In our case, whole body positron emission tomography and cranial MRI did not show another metastatic lesion. The severity of the primary neoplasm, as well as other metastases, patient age and clinical performance affect to take a decision for surgery (7). In literature, surgery was noticed better survive compared to conservative treatment with a median survival time of 9.4 vs. 5 months and 7.4 vs. 2.6 months with and without surgery, respectively $(11,12)$. Surgical treatment provides rapid recovery of pain and neurological deficits, also surgery is effective for increasing the patient's quality of life (2,5,7). Management (surgery, radiotherapy or conservative) of these metastasis should be decided case by case.

\section{Conclusion}

Intradural extramedullary carcinoid metastases of nonneurogenic origin are extremely rare. We described an intradural extramedullary metastasis of a rather uncommon lung cancer. The incidence of rare localization of metastasis is increasing as a result of development in diagnostic tools and treatment methods.

\section{Conflict of Interest: None}

\section{References}

1. Ansink BJ, Van Lambalgen HC, Davies G. Metastatic carcinoid tumor compressing the cauda equina. Letter to the editör. J Neurol Neurosurg Psychiatry 1984;47:652
2. Blondet E, Dulou R, Camparo P, Pernot P. Lumbar intradural metastasis of a primary carcinoid tumor of the lung. J Neurosurg Spine 2005;2:231

3. Li D, Brennan JW, Buckland M, Parkinson JF. Bronchogenic carcinoid metastasis to the intramedullary spinal cord. Journal of Clinical Neuroscience 2010;17:1196-8

4. Chow TS, McCutcheon IE. The surgical treatment of metastatic spinal tumors within the intradural extramedullary compartment. J Neurosurg 1996;85:225-30

5. Frey I, Le Breton C, Lefkopoulos A, et al. Intradural extramedullary spinal canal secondary neoplasms: $\mathrm{Mr}$ findings in 30 patients. Eur Radiol 1998;8:1187-92

6. Schick U, Marquardt G, Lorenz R. Intradural and extradural spinal metastases. Neurosurg Rev $2001 ; 24: 1-5$

7. Wostrack M, Pape H, Kreutzer J, Ringel F, Meyer B, Stoffel M. Surgical treatment of spinal intradural carcinoma metastases. Acta Neurochir 2012;154:34957

8. Rao KC, Jhaveri HS, Gellad FE. Carcinoid tumor with intradural spinal metastases. J Comput Tomogr 1998;12:258-60

9. Perrin RG, Livingston KE, Aarabi B. Intradural extramedullary spinal metastasis. A report of 10 cases. J Neurosurg 1982;56:835-7

10. Travis WD, Colby TV, Corrin B, Shimosato Y and Brambilla E (eds): Histological Typing of Lung and Pleural Tumours. World Health Organization International Histological Classification of Tumors, XIII. 3rd edition. Springer-Verlag, Berlin/Heidelberg, 1999.

11. Dam-Hieu P, Seizeur R, Mineo JF, Metges JP, Meriot P, Simon H. Retrospective study of 19 patients with intramedullary spinal cord metastasis. Clin Neurol Neurosurg 2008;111:10-7

12. Kalaycı M, Cağavi F, Gül S, Yenidünya S, Açikgoz B. Intramedullary spinal cord metastases: diagnoses and treatment-an illustrated review. Acta Neurochir 2004146:1347-54 